This item was submitted to Loughborough's Research Repository by the author.

Items in Figshare are protected by copyright, with all rights reserved, unless otherwise indicated.

\title{
Increasingly geopolitical: EU's eastern neighbourhood in the age of multiple crises
}

PLEASE CITE THE PUBLISHED VERSION

https://doi.org/10.1007/978-3-030-25606-7_2

PUBLISHER

Palgrave Macmillan

VERSION

AM (Accepted Manuscript)

\section{PUBLISHER STATEMENT}

This is a post-peer-review, pre-copyedit version of a chapter published in Resilience and the EU's Eastern Neighbourhood Countries: From Theoretical Concepts to a Normative Agenda. The final authenticated version is available online at: https://doi.org/10.1007/978-3-030-25606-7_2.

\section{LICENCE}

CC BY-NC-ND 4.0

\section{REPOSITORY RECORD}

Nitoiu, Cristian. 2019. "Increasingly Geopolitical: Eu's Eastern Neighbourhood in the Age of Multiple Crises". figshare. https://hdl.handle.net/2134/11974104.v1. 


\title{
Increasingly geopolitical: The EU's eastern neighbourhood in the age of multiple crises
}

\begin{abstract}
The recent decade has marked the increasing emergence of disorder in the neighbourhood of the European Union (EU). South of its borders, the Arab spring or the migrant crises have underlined the vulnerabilities of the EU to a whole host of exogenous threats. The Ukraine crisis has made both the EU and Russia reconsider the geopolitics of their shared neighbourhood. The chapter shows how the Ukraine crisis has moved relations between the EU and Russia from geopolitical competition to geopolitical conflict, a process which has been primarily played out in the post-Soviet space. The chapter also contends that the increase in geopolitics has prompted the EU to build its resilience towards external development in the eastern neighbourhood.
\end{abstract}

Keywords: European Union, Russia, status, geopolitics, eastern neighborhood, resilience 


\section{Introduction}

The recent decade has marked the increasing emergence of disorder in the neighbourhood of the European Union (EU). South of its borders, the Arab spring or the migrant crisis have underlined the vulnerabilities of the EU to a whole host of exogenous threats. In the eastern neighbourhood $^{1}$, the EU has been forced to deal with the assertive behaviour of Russia, the resistance of the states in the region to modernisation and democratisation, as well as the prevalence of geopolitical pressures. For much of the post-Cold War period the EU tended to ignore the latter aspect, and promote a model of governance that focused on principled behaviour and side-lined geopolitics (Nitoiu \& Sus 2019). However, this approach overlooked the fact that most states in the neighbourhood (including Russia) perceive geopolitics as a key driver in world politics. Even more, in the eve of the success of the enlargement towards Central and Eastern Europe (CEE), the EU emphasised through its Security Strategy that the neighbourhood represented a ring of friends, a geographical space that was conducive to EU leadership and the expansion of European integration (Council of the European Union 2003). Conversely, the recent years have marked a sharp change in the EU's approach towards the neighbourhood, which is now seen as a ring of fire, and an important source of (even existential) threats (European Commission 2015). Acknowledging its vulnerability in light of the importance of geopolitics and the threats originating from the neighbourhood, the EU has reframed its ambitious approach. The crisis-mode response of the EU has been to focus on the concept of resilience. This has entailed ensuring its own resilience to both internal and external threats, as well as, in the eastern neighbourhood, providing the tools to the states in the region to enhance their own resilience in order to limit potential threats to the EU.

In this context the chapter aims to explore the emergence of geopolitics as the most salient factor driving disorder in the eastern neighbourhood, and its consequences on the EU, Russia and the states in the region. Moreover, increasing geopolitical pressures are seen as a key stumbling block for ensuring and enhancing the resilience of the EU and its eastern neighbours. In doing so, the chapter argues that geopolitics has come to play a central role in the eastern neighbourhood primarily due to the efforts of the EU and Russia to enhance their status in world politics. The chapter proceeds by discussing the way geopolitics has emerged as a key factor shaping the stability of the eastern neighbourhood, and the way it impacts the

\footnotetext{
${ }^{1}$ In this chapter the concepts eastern neighborhood, shared neighborhood and post-Soviet space are used interchangeably.
} 
resilience-building efforts of the EU and the states in the region. In the next sections the analysis focuses on accounting for the emergence of geopolitics. It first outlines a series of theoretical insights regarding the role of geopolitics and status in world politics. The following two sections then map the way the EU and Russia's foreign policies and approaches towards the post-Soviet space have been shaped by status concerns and sought to act in the geopolitical structure of the region. Section four takes the argument forward and focuses on how the EU and Russia perceived each other's status and status-seeking efforts in the post-Soviet space since Putin started his third term as president in 2012. The chapter finds that both Russia and the EU have been exerting influence over the post-Soviet space as a key prerequisite for enhancing or maintaining their status in world politics which has moved their relationship from geopolitical competition to geopolitical conflict.

\section{The emergence of geopolitics in the eastern neighbourhood}

In this chapter we apply a rather traditional understanding of geopolitics, whereby it is seen as the projection of power across borders in a specific geographic area. The concept describes both the ability of international actors to project their power in world politics, as well as the structural aspects that underline the way power flows across borders. A key underpinning idea is that the nature of power exchanges across borders and among states shapes questions of cooperation, cooperation and conflict. Power is also the main currency that influences the status claims of states (Youngs 2017). Hence, acting in a geopolitical manner both in terms of begin able to effectively project power across one's borders and to manage the various structural pressures is a key marker for higher status in world politics. In its traditional conceptualisation, geopolitics assumes that states at the top of the hierarchy of international relations are able to maintain a sphere of influence in their neighbourhood and have it recognised by equally powerful actors (Nitoiu \& Sus 2019).

The recent emergence of geopolitics in the eastern neighbourhood has affected the main aspects that characterise the traditional understanding of the concept. Firstly, power seems to have become a key driving force in structuring relations between international actors in the region (Youngs 2017). Russia and the EU have sought to increase their power by achieving or maintaining influence in the post-Soviet space. While up until the Ukraine crisis, both Russia and the EU highlighted the mutual benefits (for each other and the states in the 
region) that their power projection promised to bring, following the onset of the conflict the focus has shifted to the need to promote their own interests together with enhancing resilience. On their part, the post-Soviet states have demanded increased presence and power projection from the EU and Russia, in order to achieve resilience from external threats (for example, in the case case of Ukraine and Georgia, greater EU influence and power projection is seen to counter Russia's negative actions). Secondly, the salience of geography has increased, as both the EU and Russia have developed mutually exclusive regional integration projects that seek to delineate geographic spaces of inclusion and exclusion (Smith 2016). Pitted against these two contradictory alternatives, the neighbourhood states have had to make a stark choice between one and the other. In practice, for countries like Ukraine or Armenia this has meant relinquishing their traditional multivector approach that has contributed to stability in the region (Forsberg 2014). To that extent, there a is heated debate in the literature on whether the dichotomous choices given to the neighbourhood states has increased their agency or rather decreased their resilience to deal with external and internal threats (Nitoiu \& Sus). The development of the Ukraine crisis (and of the post-Maidan system of governance in Kyiv) highlights that for the short-term, giving up a multivector approach, has left the country at best in a state of limbo and stagnation.

Thirdly, a more important role for geopolitics in the eastern neighbourhood has seen the rehashing of great power politics, and its emphasis on the concept of sphere of influences. This perspective tends to take agency away from the small states in the region, and place them at the mercy of the great powers in their neighbourhood (Freedman 2016). Thus, geopolitics underlines the struggle between Russia and the EU in order to assert (and gain recognition for) their spheres of influence in the eastern neighbourhood. States such as Belarus or Georgia are forced by structural geopolitical pressures to accept their status as mere peons in the sphere of influence of either the EU or Russia. From this perspective, their resilience and to some extent agency can be assured by embracing the influence of one of the great powers, rather than resisting it. Another strategy that has been used by the post-Soviet states has been to pit great powers against each, in order to get as many benefits as possible. For example, while Belarus and Armenia are deeply entrenched in Russia's sphere of influence they have on various instances used cooperation with the EU in order to loosen the reins of Moscow (Allison 2013).

Finally, some of the key geopolitical challenges for the EU in the neighbourhood are represented by the range of frozen or protracted conflicts which involve the states in the region. These conflicts have at their root the dissolution of the Soviet Union and the presence 
of significant minorities (usually Russian speaking) on the territory of the post-Soviet states. While in the case of the conflicts in Georgia (Abkhazia and Ossetia), Moldova (Transnistria) or Ukraine (the Donbas region) separatism is driven by Russian speaking minority, in Nagorno Karabach the Armenian minority has been striving to gain independence from Azerbaijan. In all of these cases, Russia maintains a military presence either through peacekeeping force or support for local militias (as in the case of the conflict in eastern Ukraine). For the Kremlin, managing these conflicts in such a way that does not lead to their resolution is a key tool for marinating a grip on the post-Soviet states, and managing the geopolitical structure of the region (or maintaining its sphere of influence). However, this poses serious risks for the EU, as the potential for these frozen conflicts is rather with violence flaring up every now and again. Enhancing the EU's resilience in this case would entail greater involvement in the resolution of the frozen conflicts, while also managing any geopolitical tensions that can appear in relations with Russia. To some extent, the 2015 revision of the ENP and the 2016 global strategy strike a fine balance, as they highlight the need for the EU to enhance the its own resilience and that of the eastern neighbourhood in dealing with frozen conflicts, but equally does not include clear strategies that would collide even further with Russia interest.

The recent years have also highlighted a wide range of existing and new structural geopolitical pressures in the region. Arguably the most salient series of geopolitical pressures has been caused by the onset of the Ukraine crisis. This event not only deeply entrenched Ukraine (the EU and the West) in a conflict with Russia, but also contributed to revising the post-Cold War security order in the post-Soviet space and on the European continent. Moscow's annexation of Crimea or its actions in Eastern Ukraine have put in doubt the security and sovereignty of the states in the eastern neighbourhood. Moreover, the rather unopposed way in which Russia acted during the Ukraine crisis has strengthened the feeling that geopolitics is a central driver in the post-Soviet space. A focus on resilience in dealing with geopolitical pressures rather than tackling directly the Kremlin's actions has been the preferred response for both the EU and the neighbourhood states. In the same vein, the proEuropean post-Soviet states (like Ukraine or Moldova) are in a vulnerable position, as the EU might in the future decide that enhancing its resilience involves striking a deal with Moscow and leaving the post-Soviet space in Russia's sphere of influence.

The clash of Russian and EU integration projects in the eastern neighbourhood represented a key trigger for the Ukraine crisis. Nevertheless, it is also a more long-term geopolitical pressure that trapped post-Soviet states into a situation, where they need to 
choose between two mutually exclusive integration projects. Ensuring the resilience of eastern neighbours of the EU in this regard would see the two integration projects becoming more complementary, in order not to create a binary choice. The disintegration of the Soviet Union created a wide range of long term geopolitical pressures which still influence the postSoviet space. For example, the issue of unresolved borders together with the presence of large Russian ethnic speaking people in the eastern neighbourhood has put the countries in the region in a position of vulnerability in relation to the influence of the Kremlin (Allison 2013). In what follows the chapter analyses one of the central causes for the emergence of geopolitics in the eastern neighbourhood: i.e. the quest for status of Russia and the EU.

In the context of the rise of geopolitics, the last years have seen the EU embrace the need to enhance its resilience toward a whole host of challenges. The concept of resilience focuses on the ability of individuals or groups to adapt to and cope with various risk, events, or negative developments. This entails developing new strategies and policies, together with predicting, preventing and managing crises or events that can have negative consequences for the EU. The chapter argues that crises such as the migrant crisis, Brexit or the Ukraine crisis can be seen as key triggers for the EU to develop strategies for enhancing its resilience. This has occurred both in relation to internal challenges (such as the rise of populism and Eurosceptic) as well as potential risks identified in the EU's neighbourhood and the wider international arena. In the eastern neighbourhood particularly, such challenges range from protracted conflicts, migration, political instability, the presence of authoritarian regimes, energy (in)security, the aggressive actions of states such as Russia, cross border crime or migration. While during the 2000s the EU applied a rather ambitious and idealistic approach towards the region which emphasised extending European integration, during the last years, the focus on resilience has implied scaling down of ambitions.

The chapter argues that the increasing importance of geopolitics in shaping the order of the eastern neighbourhood compounds the EU's ability to enhance its resilience. For much of the post-Cold War period the EU designed its foreign policy based on the idea that geopolitics was nothing more than a remnant of the past which led to the two world wars. Geopolitics entails higher levels of unpredictability in the evolution of the security order in the eastern neighbourhood. In the same vein, it puts at odds the EU and Russia, who under geopolitical constraints have to increase their power and influence in their shared neighbourhood as a prerequisite for assuring their security and enhancing their resilience. Moreover the chapter shows that both the EU and Russia have sought to enhance their status in world politics by 
attaining greater presence in the eastern neighbourhood, which, in turn, has made their relationship to geopolitical competition and conflict.

\section{The status-geopolitics nexus in world politics}

Status is considered in this chapter to encompass the collective beliefs held in international arena about a state's abilities and characteristics, and the way these translate into rights and responsibilities in international relations. Achieving or maintaining one's status (statusseeking) can be considered one of the main driving forces that influence the behaviour of states in world politics (Beasley 2012). The chapter focuses on the way the status-seeking efforts of Russia and the EU have affected the emergence geopolitics in the post-Soviet space.

The concept of status is ultimately intersubjective as it shaped by the interactions between states, and originates from the dynamics of their relationships (Lindemann \& Ringmar 2014). Consequently, status is ultimately conferred through the recognition of other states, which can be both formal (e.g. inclusion in various multilateral arrangements) or informal (e.g. at the level of political elites). Nevertheless, states will assess their own status based on a series of more or less seemingly objective criteria mainly related to the sources of power at the disposal of states. Even though status plays a key role in international relations, it is very much a fluid concept which is shaped by interactions between states, but more importantly by their evaluations of themselves and others in international relations. This makes status open to interpretation particularly by states that are not happy with their current status in world politics (Paul et al. 2014).

Relations between states are structured by status concerns, as states will generally use these links as a vehicle for maintaining or improving their status in international relations. Status can thus lead to both conflict and cooperation among states, as mutual recognition of status generally leads to cooperation while discrepancies between a state's self-evaluation of its status and that conferred by other states will lead to more conflictual behaviour (Forsberg 2014). China is a good example of a state whose status has been increasingly formally recognised by the West through inclusion in various multilateral frameworks which has led to Beijing buying into the current Western-led world order. Conversely, Russia has been feeling 
aggravated since the end of the Cold War due to the perception that the West has not conferred it the status of great power, which has made Moscow increasingly assertive.

States employ various strategies in their status-seeking efforts. The most obvious is posturing, i.e. displaying various sources of power at the disposal of the states in a bid to convince other states to grant recognition for a higher status. Even though posturing tends to have a negative connotation in world politics, using international aid or global climate change policy allows states to display sources of power which do not threaten other states and don't create security dilemmas. Status-seeking is even more important when it comes to states for which there is an internal or external expectation of rise or decline. A state on the rise will try to change various aspects of the world order, if those don't allow it achieve a higher status. Similarly, declining states will either try to maintain the current world order in order to stop their decline or to try to revise it according to the moment they achieved high status (Suzuki 2008). Status-seeking from rising or declining states can, thus, sometimes lead to both disruptive but also opportunistic behaviour. Russia is a very interesting example here, as it currently seems to be both rising and declining. Its assertive and disruptive behaviour in relation to the liberal Western-led world order has arguably elevated it as the main driver for revisionism in world politics (Tsygankov 2016).

The efforts of states to enhance their status often tend to collide and lead to geopolitical competition and even conflict in the international arena. Even though win-win situations that describe mutually beneficial status-seeking efforts can exist, they are impeded by the fact that the quest for status is generally inward looking. To that extent status-seeking is very often a reflection of the endogenous characteristics of states rather than structural aspects of the world order. That means that even though geopolitics might point to the potential emergence of deep competition and conflict, states will primarily look inwards in designing and putting into practice their status-seeking efforts. Moreover, enhancing one's status while overlooking geopolitical pressure in the international arena is a clear path towards aggravating the status claims of other states.

Understanding and managing pressures pertaining to the geopolitical structure of world politics is a key asset that states have to develop and possess in order to have their status recognised by their peers. In the case of the post-Soviet space, acting in disregard of the way geopolitics shapes the region has gradually led to a situation where the EU and Russia have increasingly developed their status-seeking efforts in a mutually exclusive manner. The chapter shows that while Russia has been aware of the salience of geopolitics in world politics and the post-Soviet space, the EU has sought to build its status by ignoring 
geopolitical pressures and promoting a new type of governance which transcends geopolitics and emphasises the role of universal norms, value sand regulations.

\section{The EU's status-seeking efforts and geopolitics}

Achieving higher status in world politics has been one of the most important forces driving the EU's foreign policy. The roots of this can be traced back to the 1960 s to the ambitions of creating a Defence Union as well as a political one, where the member states would act unitedly in foreign and security policy (Allen \& Smith 1990; Duchene 1972). One of the more important debates about how the EU could achieve greater status in world politics has been centred around the need to build and develop a foreign policy akin to a nation state or to create a sort of sui generis foreign policy - even though the emphasis has not been on geopolitics (Telò \& Ponjaert 2013; Toje 2010; Vogler \& Bretherton 2006). For the largest part of the post-Cold War period it seemed that the latter perspective gained more traction among EU policymakers (and academics), with the EU embracing (and being self-seduced by) the normative power Europe (NPE) concept and rhetoric (Manners 2002).

The NPE self-image has thus dominated the way the EU understands the role of geopolitics and status in world politics. Born out of the need to come up with a foreign policy identity that would match the EU's assets and limitations, NPE framed achieving a higher status in world politics as not the main concern for the EU. Rather than focusing on the geopolitical structure of world politics, the EU would be concentrated on bettering the life of people around the world, by promoting the range of norms and values that have proven so successful on the European contentment in preventing interstate conflict (Manners 2002). In turn, successfully shaping normality in world politics would enhance even further the EU's status and base it on the progressive identity of distinctiveness in world politics (Diez 2005). Only recently, when faced with the increasingly disordered neighbourhood and multiple crises has the EU started to include more geopolitical aspects in its understanding of world politics (Morgherini 2017; Smith 2016). Consequently, the metrics for judging its own status have been expanded to include aspects of hard power, and geopolitics, decreasing the EU's self-evaluation. The EU's recent shift in foreign policy can be seen as recognition that other states had never forgone the salience of geopolitics (Youngs 2017). 
The neighbourhood has been during the last two decades a key priority in EU foreign policy. The main rationale behind this is the idea that if the EU is not able to develop a strong presence in the post-Soviet, it would be difficult to imagine how the Union can play in important role in the international arena (Council of the European Union 2003; European Commission 2003; Prodi 2002). Moreover, in world politics there is an expectation that higher status international actors are able to shape the regional order in their backyard and act in a geopolitical manner (Freedman 2016). Hence, the EU's approach towards the neighbourhood has been to a large extent shaped by the need to prove to itself that its ambitions of having a strong presence in the international arena can be fulfilled. Moreover, the post-Soviet space has been a key region for the EU to test the extent of its influence through normative power. Unlike the case of former Communist states from CEE, the EU has taken off the table the prospect of membership. The post-Soviet states have been asked to adopt wholeheartedly the EU's menu of values norms and regulations based on the power of attraction of the EU, rather than on the end goal of membership.

The EU, due to the success of the enlargement, saw itself as already an established important international actor (Council of the European Union 2008; European Commission 2007). This, together with the fact that it now started bordering the post-Soviet space made the EU set its sights on integrating the eastern neighbourhood (building what Russia perceived as a geopolitical project). The EU formalised this approach through the European Neighbourhood Policy (ENP) which sought to assist the countries in the EU's neighbourhood (both eastern and southern) to adopt the EU's menu of regulations, norms and values. Securing the borders of the EU, but also proving that the EU can have a major presence in the neighbourhood (that would lead to a global presence) were the main reason for the EU's push towards the post-Soviet space - the economic benefits of the spreading European integration to the post-Soviet space were indeed part of the decision, but not a prime factor (European Commission 2003; Ferrero-Waldner 2005). Following enlargement and the formulation of its strategy towards the neighbourhood, the EU started to gradually embrace the idea that it had proved that it can act as strong international actor. Even more, the normative power rhetoric originating from academic writing became transposed into EU official documents as a way of posturing that the EU is not only a strong international actor, but also a distinctive one which focuses on the promotion of norms values and regulations, not particularly in order to further its own interests, but those of peoples around the world (Füle 2010). 
The EU interpreted the 2008 Georgian-Russian war as evidence of the fact that Russia would not permit the altering of the security order in the post-Soviet space, but would not be so concerned with the EU shaping the economic order in the region (Füle 2010). Hence, the EU revamped its approach towards the eastern neighbourhood through the Eastern Partnership (EaP) and the creation of tools such as the Association agreements (AAs) and Deep and Comprehensive Free Trade Areas (DCFTAs), which were meant to intensify the integration of the post-Soviet states (Council of the European Union 2010). In doing so, it was oblivious of the fact that Russia viewed this move as a geopolitical threat, and equated economic interests with security ones, as the EaP, the AAs and DCFTAs were seen as part of a traditional liberal strategy of diluting Russia's power in the post-Soviet space.

In order to implement its agenda in the post-Soviet space the EU has the whole spectrum of tools at its disposal in foreign policy, based on its main metrics of status (e.g. economy, power of attraction, or diplomatic relations). These strategies have been framed under the broad goal of persuading through equal dialogue with the post-Soviet states to adopt the EU's values and embark on a series of democratic reforms (European Commission 2015). The EU has focused on supporting liberal elites to power and working with civil society groups that push for European integration, a process that would yield clear benefits for the neighbourhood countries in the medium to long term. In practice, persuasion implied politicisation and conditionality attached to deepening economic cooperation. As various analyses have pointed, in the aftermath of the start of the Ukraine crisis, the EU fooled itself in believing the universality of its norms and values, and ignoring the fact that most of its relations with the post-Soviet states were deeply unilateral, asymmetrical, and affected by geopolitical constraints (House of Lords 2015). Hence, following the Ukraine crisis, and recent illiberal developments in Moldova, the EU has started to acknowledge that without securing short-term benefits for peoples in the post-Soviet space, its power of attraction, influence and resilience in the region are bound to decrease (Morgherini 2017; Youngs 2017).

Status-seeking in the post-Soviet space on the part of the EU has been a more intersubjective affair than in the Union's broader approach to world politics. This can partly be explained by the fact that post-Soviet elites have been quite opportunistic, and have developed a habit of telling the EU what it wants to hear (Baltag \& Smith 2015). The EU has rarely questioned this commitment, and has operated based on the assumption that it was indeed influencing the region in a meaningful manner (and thus enhancing its status). However, in practice, the post-Soviet states have made only painful and sometimes 
contradictory progress in living up their commitments to the EU. Recognition from Russia has also been a key aspect in the EU's approach towards the post-Soviet space. But as will be seen in the next sections, the EU acknowledged and to some extent demanded from Russia recognition only from a higher moral ground, ignoring the geopolitical structure of the eastern neighbourhood.

\section{Russia's status-seeking efforts and geopolitics}

Much of Russia's foreign policy during the post-Cold War period has been shaped by the desire to recover the status held by the Soviet Union. Following the dissolution of the Soviet Union, Russia experienced during the 1990s a period of sharp decline in the background of the implementation of liberal reforms, and what was seen as weak leadership from Yeltsin. Even though during this time Moscow seemed to be embarked on a path towards integration in the liberal world order, many stakeholders in the country still believed that Russia should play an important role in international relations (Webber 2000). The 1900s led to entrenching in the Russian psyche the idea of Western betrayal (Lukin 2016). Once the narrative of Western betrayal became mainstream in Russian society, Moscow's main foreign policy goal shifted to recapturing the former status of the Soviet Union (Neumann 2008). Putin, in turn, especially since his second term, has banked on this and framed his leadership as the only one capable of returning to Russia its former status and managing the geopolitical structure of the post-Soviet space. Status-seeking has also influenced the development of a strong state in Russia, with the president exercising control on most areas of governance (Sakwa 2007). If during his first two terms as president Putin frequently stated that Russia should be treated as a great power, starting with his third term (and especially since the Ukraine crisis), there is an implicit assumption in the Russian narrative that the country has already achieved this status (Putin 2014, 2016; Rossiyskaya Gazeta 2013).

Russia thus perceives status to be one the most important aspects of world politics. Unlike the EU, status is seen more in geopolitical terms by Moscow and is linked to the recognition of a series of rights which only higher status actors (great powers) are privileged to possess (Forsberg 2014). Because in this interpretation of status geopolitical concerns have a central role, concepts such as spheres of influence and buffer zones are one of the key rights allotted to great powers. These notions involve the legitimacy of great powers to shape the regional order in their backyard: e.g. influencing the foreign and domestic policies of the 
countries in the region. The concept of buffer zone delineates the need to have neutral zones between the spheres of interest of various great powers. Having the status of great power also implies that other great powers recognise the legitimacy of other states' spheres of interests and subsequent buffer zones.

Domestically, the quest for status has also fuelled the besieged castle rhetoric, which puts the blame on the West for encircling and trying to virtually destroy Russia. This type of discourse has framed in the Russian public sphere status claims as a matter of survival in the context of increasing geopolitical pressure from the West. The high levels of approval regarding Russia's actions in Crimea or Eastern Ukraine can be thus attributed to the perception that they have contributed to Russia attaining higher status. Further evidence for this comes from the claim that Russia was able to influence domestic politics in a series of Western countries, most notably the US and the UK.

The preoccupation with status has historical roots in Russia's past, and is very much ingrained in the way the Russian society perceives itself and relations with the outside world (Neumann 2008). This level of entrenchment of status concerns in the Russian psyche makes both the public sphere and politicians or the army push for Russia to regain the former status of the Soviet Union and effectively manage pressures pertaining to the geopolitical structure of world politics. Ultimately, for Russia, recognition of the great power status and the range of rights and benefits attached to it is something that Moscow deserves from the West (Tsygankov 2016).

\section{Status-seeking and the post-Soviet space}

The post-Soviet space has been since the end of the Cold War a key referent object in Russia's status-seeking efforts, as the main source of geopolitical pressure and constraints. The (voluntary) loss of the region following the dissolution of the Soviet Union was seen by many in Russia as a message to the West that Moscow was ready to be integrated as a full and equal member of the liberal world order (Neumann 2008; Webber 2000). From the perspective of status, Moscow's aim would be to gain recognition of its legitimate claims for exerting influence on the post-Soviet space (and the non-intrusion of other powers such as the US or the EU). Managing the geopolitical structure of the region is considered to be testimony to Russia's ability to act as strong international actor more globally (Putin 2014).

The most important source of power that allows Russia to claim and exert influence over the post-Soviet states is undoubtedly the presence of its military and intelligence 
personnel in the region, which allows it to manage the geopolitical structure (Allison 2013). For example, in Armenia Moscow commands control due to the fear in Erevan, that in the absence of Russian troops, the country would be extremely vulnerable in relations to its neighbours (Azerbaijan and Turkey). Conversely, in Ukraine or Moldova where Russian troops have been stationed more or less lawfully, the threat of a potential use of those military capabilities acts as a constant constraint for policymakers (Tudoroiu 2012). Due to the asymmetrical military relationships between the post-Soviet states and Russia, most of them fear (and have sought to become resilient) in various degrees a potential Russian intervention coupled with the loss of autonomy in foreign policy.

In practice, Russia has often, banking on its military prowess, employed more soft metrics of status in the region. This primarily focused on non-politicised economic cooperation, support for Russian speakers and the creation of a web of regional integration initiatives. For example, in terms of economic cooperation, Russia has not attached any sort of specific political conditionality on these countries, but it has demanded from them a broader notion of ceding their autonomy in foreign policy: i.e. either having friendly foreign relations with Russia, or at least being neutral and not developing close relations with the West. In turn, in order to get the geopolitical upper hand, Russia offers what could be seen as short term incentives, such as loans, cheap prices for natural resources, or support for various (corrupt and authoritarian-inclined) political elites.

Russia's status-seeking strategies in the region are characterised by manipulation and coercion rather than persuasion (Sherr 2015). If short-term incentives associated with nonpoliticised economic cooperation are not effective, Russia is not shy in using more or less direct threats in determining its desired outcome in the region. The Kremlin has indeed used military intervention at times (e.g. Georgia), but has also been very careful in maintaining a certain level of strategic uncertainty that would allow it to both send a strong message to the states in the region, whilst also denying any aggressive moves. What has been termed as hybrid warfare (Renz 2016) is to large extent the result of Russia's strategic uncertainty approach in managing the geopolitical structure in the region: e.g. sending little green man in Crimea and denying the presence of Russian forces, or not acknowledging direct support for rebel groups in eastern Ukraine.

The path to geopolitical confrontation: Perceiving the other's status and status-seeking 
The previous sections highlighted how Russia and the EU's own status-seeking efforts influenced their approach towards the post-Soviet space. This section takes the argument forward and emphasises that with Putin's third term as president in 2012 their EU and Russia's status-seeking efforts have gradually moved their bilateral relationship to geopolitical competition and conflict in the eastern neighbourhood. The election of Putin for a third presidential termed marked the end of Russia's desire to be part of the liberal world order and use this as a strategy for gaining recognition from the West of a higher status. By the end of Medvedev's presidency, it was clear for Putin that the West would not revise the term of the post-Cold war order on the European continent and treat Russia as an equal (Trenin 2014). Russia, thus, needed a new sort of drive and strategy in foreign policy in foreign policy. The promotion of conservative values has formed since then a key pillar of Putin's domestic politics - with an ever closer alliance with the Orthodox church - but also of the model and values that Russia seek to promote in its external relations. A second component of Russia new civilizational model placed it at the centre of Eurasian civilization, with Moscow driving Eurasian integration and the Eurasian Economic Union. The formulation of these two components of Russia's new or revised civilization model, together with its decisive military actions in Ukraine or Syria, have shifted the Kremlin's discourse to argue that Russia has already acquired the great power status and that it expects to be treated accordingly by the West (Putin 2016).

Nevertheless, in defining what recognition of this status would mean in practice from the West, Russia has tended to apply strategic uncertainty, never really disclosing the extent of its demands, and having an opportunistic approach in trying to get as many benefits as possible with each opportunity. The somewhat radical Russian change of mind regarding the EU and liberal world order can also be attributed to the fact that Moscow started to perceive the EU as a real threat to its influence in the post-Soviet space (Putin 2014). Up until the summer of 2013 Russian leaders seemed not to be very concerned with the AA offered by the EU to the three post-Soviet states, thinking that member states friendly to Moscow (e.g. Germany or Italy) or pro-Russian elites in these Georgia, Moldova and Ukraine would derail the process. The autumn of 2013 and Vilnius summit made Russia recognise the fact that the EU was keen to shape the geopolitical structure and order of the post-Soviet space and would mount a serious challenge to Moscow's influence in the region (Rossijskaja Gazieta 2013). This level of perceived geopolitical threat from the EU in the post-Soviet space has remained salient since the Vilnius summit, regardless of the fact that there is now a perception in Russia that 
due to the migrant crisis, Brexit, or the Eurozone crisis, the EU is bound to disintegrate and fail in the future (Walker 2016).

The EU, especially following the Ukraine crisis, started to realise that the alarm bells raised by some of the CEE member states regarding the need to increase the EU's resilience in relation to Russia's aggressive intentions in the post-Soviet space were in fact justified. European policymakers suddenly woke up (also due to the Arab spring or the migrant crisis) to the realisation that what in 2003 was framed as a ring of friends was now a ring of fire and source of instability at the Union's borders (European Commission 2015). This has led to realisation that Realpolitik and geopolitics still dominates world politics and the mindset or behaviour of other state (e.g. Russia). Regardless of this realisation the EU still stated its commitment to promoting its norms and values in international relations, but also its resilience in the face of multiple crises both in its neighbourhood. The revised ENP and Global Strategy (European Commission 2015; Tocci 2016) still see the EU as having some sort of normative power, but now acknowledge the important geopolitical threats that liberal democracy and the eastern neighbourhood are facing from states like Russia, as well as the subsequent need to enhance the EU's resilience to such risks. The EU's perception of Russia has also changed, as it views Russia as an important international actor, even though Moscow's economic power is similar to those of some bid range member states such as Italy or Spain (Morgherini 2017). Moreover, the EU has recognised Russia's aggressive moves and intentions in the post-Soviet space and that Moscow is a threat to the liberal world order, but it has not really strengthened its geopolitical presence in the post-Soviet space besides developing a new narrative with the concept of resilience as the centrepiece.

\section{Conclusions}

With the onset of the Ukraine crisis, as well as the other pressing crises experienced by the EU (e.g. the Eurozone crisis, the Arab spring, the migrant crisis, or Brexit), the idea that geopolitics is a driving force in the eastern neighbourhood has taken root in the academic and policy spheres in the region and Europe. Dealing with structural geopolitical pressures has pointed the EU and its eastern neighbours to aim to enhance their resilience. In this context, 
the aim of the chapter was to analyse the emergence of geopolitics by looking at the way the status-seeking efforts of Russia and the EU have clashed during the last two decades. The chapter argued that effectively managing and responding to the geopolitical pressures pertaining to the post-Soviet space has been for both Moscow and Brussels a key perquisite for achieving a higher status in international arena. Nevertheless, both actors have employed different tools and strategies in order to shape the post-Soviet space and increase their status. While Russia has a more geopolitical interpretation of status and relies primarily on its sources of hard power (nuclear weapons or other military capabilities), the EU tends to pursue a more norms-based strategy aimed at persuasion and the promotion of its norms, values and regulations. The chapter also argued that Russia and the EU have indeed paid attention to what they perceived to be the status and status-seeking efforts of the other, and at times, granted each other mutual recognition. Even though during Putin's rule, Russia and the EU might have not recognised each other's desired status, their policies towards the postSoviet space have been deeply influenced by status concerns. Following the Ukraine crisis, the EU and Russia have started to perceive each other as deep existential threats, and thus conferring on the other the status of important international actor (if not great power). While this evolution has not been linear, with the atmosphere of EU-Russia relations shifting continuously from geopolitical cooperation to conflict, it is clear that currently both Brussels and Moscow do not equate gaining a higher status in international arena with developing their mutual cooperation.

The shift from geopolitical competition to geopolitical conflict in the eastern neighbourhood poses significant challenges for the EU. The chapter showed that the Ukraine crisis (together with the other crises that have engulfed the EU during the last decade) have caught the EU unprepared. For much of the post-Cold War period, the Union focused on a rather idealistic and normative approach to world politics, placing norms and values above the promotion of material interests and power politics. Consequently, the EU's resilience to geopolitical developments in the eastern neighbourhood proved to be rather limited when the Ukraine crisis erupted. This, in turn, has not only allowed Russia to maintain a state of disorder in eastern Ukraine and the other frozen conflicts in the eastern neighbourhood, but has also damaged the EU's ability to promote its integration project. The EU's response has been a process of revision and renewal which puts the concept of resilience at its core. However, this tends to downgrade its previous ambitious normative goals in the eastern neighbourhood. Even more, it places to a larger degree the onus on the eastern neighbours, as the Union argues that it provides the tools for the neighbours to increase their resilience, 
and the EU is itself resilient to the failure of the states to achieve resilience. The persistence of an EU-centric and inward approach towards the neighbours, that disregards their agency, in turn, will mostly likely not have a positive effect on their ability to build resilience. In reality, one of the key challenges that these states have been facing is the binary choice between two integration project that the EU and Russia have presented them. Resilience in this regard would imply that the eastern neighbours are afforded greater agency and allowed to opt for complementary modes of governance. As the chapter showed that status seeking and status concerns are one of the main factor that have led the order in the eastern neighbourhood to slip into geopolitical conflict, enhancing the EU's resilience would entail developing increased sensitivity towards Russia's status claims and efforts. In practice, this would entail the resumption of dialogue with Russia, (possibly with the inclusion of the views of the post-Soviet states), as well as developing clear strategies and prevention measures for dealing with the Kremlin's assertive foreign policy.

\section{References}

Allen, D. \& Smith, M. (1990). Western Europe's Presence in the Contemporary International Arena. Review of International Studies, 16(1), 19-37.

Allison, R. (2013). Russia, the West, and Military Intervention.Oxford: Oxford University Press.

Baltag, D. \& Smith, M. (2015). EU and Member State Diplomacies in Moldova and Ukraine: Examining EU Diplomatic Performance Post-Lisbon. European Integration online Papers (EIoP), 19(1), 1-25

Beasley, N. (2012). Great Powers in the Changing International Order. Boulder, CO: Lynne Rienner Publishers.

Council of the European Union (2003). A secure Europe in a better world - European Security Strategy. https://www.consilium.europa.eu/uedocs/cmsUpload/78367.pdf. Accessed 10 May 2019. 
Council of the European Union (2008). Council Conclusions on European Neighbourhood Policy.

http://www.consilium.europa.eu/ueDocs/cms_Data/docs/pressData/en/gena/98790.pdf.

Accessed 10 May 2019.

Council of the European Union (2010). Joint Statement on the Partnership for Modernisation $\begin{array}{lllll}\text { EU-Russia } & \text { Summit } & 31 & \text { May-1 }\end{array}$ http://www.consilium.europa.eu/uedocs/cms data/docs/pressdata/en/er/114747.pdf. Accessed 10 May 2019.

Diez, T. (2005). Constructing the Self and Changing Others: Reconsidering 'Normative Power Europe'. Millennium - Journal of International Studies, 33(3), 613-636

Duchene, F. (1972). Europe's role in world peace. In Mayne R. J. (ed.), Europe tomorrow: sixteen Europeans look ahead. Fontana: London.

European Commission (2003). Wider Europe - Neighbourhood: A New Framework for Relations with our Eastern and Southern Neighbours. https://www.consilium.europa.eu/uedocs/cmsUpload/78367.pdf. Accessed 10 May 2019.

European Commission (2007). The European Union and Russia: Close Neighbours, Global Players, Strategic Partners. https://eeas.europa.eu/sites/eeas/files/eu_russia_en.pdf. Accessed 10 May 2019.

European Commission (2015). Review of the European Neighbourhood Policy. http://eeas.europa.eu/archives/docs/enp/documents/2015/151118 jointcommunication_review-of-the-enp_en.pdf. Accessed 10 May 2019.

Ferrero-Waldner, B. (2005). Speech by Dr Benita Ferrero-Waldner, European Commissioner for External Relations and European Neighbourhood policy. europa.eu/rapid/pressrelease_SPEECH-05-658_en.pdf. Accessed 10 May 2019.

Forsberg, T. (2014). Status conflicts between Russia and the West: Perceptions and emotional biases. Communist and Post-Communist Studies, 47(3-4), 323-331.

Freedman, J. (2016). Status insecurity and temporality in world politics. European Journal of International Relations, 22 (4), 797-822. 
Füle, Š. (2010) The EU: a Force for Peace, Stability and Prosperity in Wider Europe. europa.eu/rapid/press-release_SPEECH-10-706_en.pdf. Accessed 10 May 2019.

House of Lords. (2015) The EU and Russia: before and beyond the crisis in Ukraine. https://www.publications.parliament.uk/pa/ld201415/ldselect/ldeucom/115/115.pdf. Accessed 10 May 2019.

Lindemann, T. \& Ringmar, E. (Eds) (2014). The International Politics of Recognition. Boulder, CO: Paradigm.

Lukin, A. (2016). Russia in a Post-Bipolar World. Survival, 58 (1), 91-112.

Manners, I. (2002). Normative Power Europe: A Contradiction in Terms? JCMS: Journal of Common Market Studies, 40 (2), 235-258.

Morgherini, F. (2017). Speech by Federica Mogherini at the Munich Security Conference. https://eeas.europa.eu/headquarters/headquartershomepage en $/ 20832 /$ Speech $\% 20$ by $\% 20$ Federica $\% 20$ Mogherini $\% 20$ at $\% 20$ the $\% 20$ Munich $\% 2$ 0Security\%20Conference. Accessed 10 May 2019.

Neumann, I. B. (2008). Russia as a great power, 1815-2007. Journal of International Relations and Development, 11 (2), 128-151

Nitoiu, C. \& Sus, M. (2019). Introduction: The Rise of Geopolitics in the EU's Approach in its Eastern Neighbourhood. Geopolitics, 24 (1), 1-19.

Paul, T. V., Larson, D. W. \& Wohlforth, W. C. (Eds.) (2014). Status in World Politics. New York: Cambridge University Press.

Prodi, R. (2002). A Wider Europe - A Proximity Policy as the key to stability. http://europa.eu/rapid/press-release_SPEECH-02-619 en.htm. Accessed 10 May 2019.

Renz, B. (2016). Russia and "hybrid warfare”. Contemporary Politics, 22 (\#),283-300.

Rossiyskaya Gazeta. (2013). Путин: Россия и Украина представляют один народ. Rossiyskaya Gazeta, https://rg.ru/2013/09/04/ukraina-anons.html. Accessed 10 May 2019.

Sakwa, R. (2007). Putin : Russia’s choice. Abingdon : Routledge. 
Sherr, J. (2015). A War of Narratives and Arms. In Chatham House (Ed.) The Russian Challenge. London: Chatham House.

Smith, M. E. (2016). Implementing the Global Strategy where it matters most: the EU's credibility deficit and the European neighbourhood. Contemporary Security Policy, 37, (3), 446-460.

Suzuki, S. (2008) Seeking "Legitimate" Great Power Status in Post-Cold War International Society: China's and Japan's Participation in UNPKO. International Relations, 22, (1), 4563.

Telò, M., \& Ponjaert, F. (2013). The EU's Foreign Policy: What Kind of Power and Diplomatic Action? Farnham: Ashgate.

Tocci, N. (2016). The making of the EU Global Strategy. Contemporary Security Policy, 37 (3), 461-472.

Toje, A. (2010). The European Union as a Small Power: After the Post-Cold War. Basingstoke: Palgrave Macmillan.

Trenin, D. (2014). The Ukraine Crisis and the Resumption of Great-Power Rivalry. Moscow: Carnegie Moscow.

Tsygankov, A. P. (2016). Crafting the State-Civilization Vladimir Putin's Turn to Distinct Values. Problems of Post-Communism, 63, (3), 146-158.

Tudoroiu, T. (2012). The European Union, Russia, and the Future of the Transnistrian Frozen Conflict. East European Politics \& Societies, 26, (1), 135-161.

Vogler, J. \& Bretherton, C. (2006). The European Union as a Global Actor. London: Routledge.

Walker, S. (2016). What Russia thinks of Brexit - and how it could gain from a fractured Europe. The Guardian.

Webber, M. (2000). Russia and Europe: Conflict or Cooperation? New York: St. Martin's Press.

Youngs, R. (2017). Europe's Eastern Crisis: The Geopolitics of Asymmetry. Cambridge: Cambridge University Press. 
